\title{
Scaling Up Community Action for Tackling Climate Change
}

\begin{abstract}
Tackling climate change requires a set of deeply intertwined geographical responsibilities whereby actors at and across different geographical scales are intimately connected. Creating effective strategies requires far more than an invocation for individual behavioural change in thinking globally and acting locally but attention to the multi-scalar conflicts, tensions and also opportunities to develop the most appropriate collective responses. In this paper, we use the example of community gardening initiatives in a large UK city, to critically interrogate the problems facing groups at the local neighbourhood level in pursuing sustainability agendas. We focus on the organisational imperative to create a multi-scalar food policy partnership at the city level as a way of confronting dominant global neoliberal urban competitiveness agendas. Our results emphasise the critical importance of scalar politics in enabling effective climate change strategies.
\end{abstract}

\section{Keywords}

Community garden, sustainability, food, scale, climate change

\section{Introduction}

Tackling climate change is a global problem that involves a multi-layered set of 'geographical responsibilities', where the actions, relations and practices of individuals and organisations acting at and across different geographical scales, from the local to the global, are intimately connected (Massey, 2004). From the outset, addressing climate change has always been visualised as a spatial and relational process (Massey, 2005), through the invocation to 'think global and act local' (e.g., Devine-Wright, 2013). Following those that 
have highlighted the limitations of individual agency in addressing the immediate challenges related to sustainability, this research focuses on meso and macro actors (e.g., Carrington, Zwick and Neville, 2016; Jones, 2010). Developing effective management initiatives at the local level must go beyond changing individual behaviours to instil a broader global consciousness (e.g., Black, Shaw and Trebeck, 2017). This relates to collective agency at the local scale as well as broader policy initiatives, such as, smart metering which seek to significantly change consumer behaviour (e.g. Hoenkamp et al., 2011). Local groups seeking to create effective strategies and practices that can contribute to environmental sustainability have to negotiate dominant agendas and actors across regional, national and supranational scales to be effective.

Through a case study of community gardening initiatives in a UK city, this paper uses a multi-scalar approach to help understand the barriers facing groups in pursuing sustainability agendas at the neighbourhood level against the backdrop of broader changes taking place in the city. There is a growing literature on the potentially important role that community gardens can play in supporting sustainability and micro-climatic change (Turner, 2011). However, in attempting to progress a global agenda of local climate action, community gardens confront a series of constraints to action in their local neighbourhoods. Challenges include security of land access, vulnerability to potential commercial development and access to funding (Crossan, et al., 2016). These challenges are in part the consequence of broader processes of neoliberal inspired urban regeneration, where city authorities are often riven by conflicts between pursuing sustainability agendas and more commercial imperatives around property based development (Crossan et al., 2016). Faced with such local barriers and constraints, community garden activists are compelled to interact across a range of different 
geographical scales with the city council, private landowners and government and nongovernmental bodies to pursue their agendas.

Within this setting, institutions across local and national governments develop what are potentially competing and contradictory multi-scalar narratives. The dominant focus since the 1980s, in common with elsewhere, has been urban competitiveness agendas. This has been positioned within a global neoliberal agenda for cities and regions to develop local competitive advantage and shift from more socially inclusive policies towards an ‘entrepreneurial urbanism’ (Harvey, 1989; Porter, 1990; Peck, 2017). This is in tension with another more recent multi-scalar initiative (connecting European, national and local scales) to address climate change and resultant lofty rhetoric around climate change transition and adaption.

To explore these issues, this paper focuses on the activities of the recently formed City Food Policy Partnership (CFPP), which brings together actors from community gardens and food groups, the city council, national government, national health service, and broader public and private sector food and health care interests, along with a team of academics in our case city. In its advocacy of community gardens as a key part of its goal to achieve a more sustainable food city and, therefore, contribute to combating climate change, we view the CFPP as a particular multi-scalar organisational vehicle that seeks to draw upon its own broader spatial networks and enrol support from influential actors at different scales of governance. A critical issue is, therefore, to examine how this scalar shift is negotiated, in a place with pre-existing dominant scalar urban management practices with all their implications for constraining community level initiatives. Further, the paper specifically explores how community gardens develop multi-scalar strategies to promote their own values around sustainability and climate 
change. It is pertinent to examine how at the community level gardening groups respond to potential interventions. In particular, does such a multi-scalar constellation present an opportunity to contest dominant agendas to advance effective sustainability strategies?

We draw upon MacKinnon's (2011) concept of scalar politics to illuminate how scale is implicated around the emergence of the CFPP. We find that the CFPP is part of a broader agenda relating to who should define, inform and conduct the urban governance process. Our

case is pertinent in highlighting the challenges to developing sustainability at a local level and the resultant need to develop multi-scalar strategies despite the inherent tensions and contradictions.

\section{Scaling up community gardens}

Community gardens are viewed as having important potential in the development of more sustainable cities (Stocker and Barnett, 1998; Ferris, Norman and Sempik, 2001; Holland, 2004). In addition to promoting the social aspects of sustainability, including, social inclusion, community building (Crossan et al., 2016; Glover, 2003; Saldivar-Tanaka and Krasny, 2004; Kingsley and Townsend, 2006; Tan and Neo, 2009), food security (Garrett and Leeds, 2015), reconnection with the socio-cultural importance of food (Turner, 2011) and physical and ecological sustainability (Delind, 2006; Stocker and Barnett, 1998), they also have capacity to improve the physical geographical environment in urban areas. Community gardening and similar activities reduce 'heat island' effects by, for example, increasing vegetation density in urban areas, improving waste management through composting, and simplifying supply chains by reducing 'food miles' and transport flows through local food production and, hence, contributing to sustainable climate change initiatives (Moskow, 1999; Pothukuchi and Kaufman, 1999; Drescher, Holmer and Iaquinta, 2006). 
The definition of community gardens is fluid and geographically variable (Garret and Leeds, 2015). This is reflected by Holland (2004: 285) who defines community gardens as "open spaces managed and operated by members of the local community for a variety of purposes". Like many post-industrial cities in the Global North, community gardening in our case city has the potential to operate at a much larger scale across the city. Four percent of the city's land area is classified as derelict, and around $60 \%$ of the city's population resides within 500 meters of such a site. Over the past decade there has been a sizable growth in the number and variety of community gardens in the city. This is partly as a response to the work of third sector bodies, funding opportunities, for example, through the climate challenge fund, and increasing political acceptance, if not encouragement of gardening initiatives through, for example, a scheme that permitted temporary (rent-free) access to derelict or under-utilised sites to those proposals that furthered community cohesion and well-being.

In an increasingly urbanised world (Cumbers, 2015), cities are pivotal spaces for sustainability governance, where an integrated approach to food is of significance to climate change (Lang, Barling and Caraher, 2009). In many cities, various government, business and civil society actors are promoting an agenda of sustainable urban foodscapes, creating 'spaces of deliberation' that bring together these actors to rethink the local food system (MoraguesFaus and Morgan, 2015). These new food governance systems can take a number of different institutional forms, including food policy councils (e.g., North America), food boards (e.g., London) and food partnerships (e.g., Brighton). Such partnerships reflect the contested nature of 'sustainability', revealing tensions between notions of sustainability and pro-growth development agendas framed within a broader context of neoliberal inspired competitiveness programmes (Peck, 2017). An increasingly important issue is how such new food governance 
initiatives negotiate multi-scalar policy landscapes to reimagine and develop alternative visions of sustainable urban development.

Drawing upon the influential work of MacKinnon (2011) we emphasise the importance of a 'scalar politics' in understanding the constraints and opportunities facing community gardens, local food initiatives and broader sustainability and low carbon urban transition agendas. There are two particular aspects to MacKinnon's schema that are important here. First, "scale and scalar relations" are "non-fixed and fluid" (2011: 27) but need to be considered in terms of "wider sociospatial processes" (ibid). Essentially, this perspective emphasises the importance of how spatial relations and scale are created through processes of social construction where scale is not the end point but the dimension through which political struggles and conflicts are played out. Following on from this, second, attention is drawn to how particular actors and movements use, create, and operationalise scale in their strategies. This relates to how they both work at and across scales and in their discursive construction of particular spatial categories and their success in operationalising them. An example from green politics is the way that climate change has been successfully cast as a global problem that needs supranational solutions, action and targets.

In developing this theorisation, we make two important contributions to management and governance pertinent to sustainability and transition politics. First, we examine the way that particular movements, projects and organisations construct their own spatial narratives and strategies to achieve their goals; for example, in invoking broader geographies of responsibility around tackling global climate change through local action and initiatives (Massey, 2004). This is challenging in the context of city authorities where urban competitiveness is often used against a backdrop of global economic integration to shift local 
resources from social welfare provision to business support and rent-seeking (e.g., Smith, 1996; MacLeod, 2001).

Second, we explore the way that local actors can mobilise their existing broader spatial networks and resources to develop their own place-based initiatives (Featherstone, 2008) as well as enrolling actors at higher spatial scales to support their agendas (Derrickson and MacKinnon, 2013). This affords an understanding of existing scalar narratives and the generation of new ones that can succeed pre-existing positions. As such, our approach enhances existing multi-level perspectives on transition (e.g., Geels, 2010, 2014), which highlight the way that higher level institutions and actors can disturb grassroots innovation. Adopting a scalar politics lens allows us to appreciate both the multi-scalar constraints from existing spatial and scalar configurations and narrative (e.g., urban agendas around securing competitive advantage in a global system) confronting local transition initiatives, and the spatial strategies that grassroots initiatives develop to "understand and enact the destabilization and decline of the fossil fuel-based regimes" (Geels, 2014: 25). This supports a critical interrogation of the potential of community gardens to contribute to broader sustainability initiatives. While there is now a substantial literature articulating the importance of community gardens for the promotion of sustainable urban living (Stocker and Barnett, 1998; Ferris, Norman and Sempik, 2001; Holland, 2004), attention as to how this potential can be most effectively realised has been very limited. The approach to scale advocated here contributes to addressing this deficit.

\section{Methods}

In developing our approach, we used a multi-method qualitative approach. Participant observations and semi-structured interviews were employed to obtain a deep understanding 
of experiences. The research commenced in 2014, and engagement is ongoing. First, over a 6 month period active participant observations were conducted across 18 community gardens (50 hours of observations). During this phase the researchers engaged in the activities of the garden alongside participants. The community gardens were selected to reflect diversity in location, scale and practice. The second phase employed semi-structured interviews involving 20 participants -9 volunteers, 8 community garden staff and 3 representatives from stakeholder groups. Interviews were around 45-90 minutes in duration and took place in the gardens. Participants included 11 males and 9 females who were heterogeneous in age, education, marital status and household composition (see Table 1 for a summary of participants). The interviews commenced with general questions about the role of the community garden in participants' lives, and continued to explore the nature and role of community gardening work in the city, the kinds of social interactions produced, organising structure and community, city and wider connections. Interviews were transcribed verbatim and pseudonyms have been adopted throughout the reporting of this research. The third phase involved participant observations at sustainable food events across the city, local grower formal and informal meetings, and quarterly CFPP meetings (approximately 82 hours of observations). These various settings provided insight into participation at scalar levels, objectives and negotiations. A field journal was used to record researcher thoughts, feelings and interactions across observations and events, alongside written minutes of the CFPP meetings.

Table 1: Participant Summary

\begin{tabular}{|l|l|l|l|l|l|}
\hline Pseudonym & Age & Marital Status & Education & Community & Employee/ \\
& Range & & & Garden & Volunteer \\
\hline George & $26-35 y r s$ & Co-habiting & University & Digley Diggers & Volunteer \\
\hline
\end{tabular}




\begin{tabular}{|c|c|c|c|c|c|}
\hline Thomas & $46-55 \mathrm{yrs}$ & Married & University & Woodside & Employee \\
\hline Mary & $56-65 y r s$ & Single & School & Woodside & Volunteer \\
\hline Annie & $18-25 y r s$ & Single & University & Secret & Employee \\
\hline Brenda & $36-45 y r s$ & Single & School & Secret & Volunteer \\
\hline William & $46-55 y r s$ & Co-habiting & School & Gorlands & Employee \\
\hline Colin & $26-35 y r s$ & Married & School & Citizens of Penny & Volunteer \\
\hline Carol & $36-45 y r s$ & Single & School & Greenlands & Volunteer \\
\hline Linda & 18-25yrs & Single & University & Gordonstone & Volunteer \\
\hline Brian & $56-65 y r s$ & Married & University & Cowhill & Employee \\
\hline Errol & $36-45 y r s$ & Co-habiting & School & Parklands & Employee \\
\hline Claire & $26-35 y r s$ & Single & University & Crowpoint & Employee \\
\hline Tony & $65+\mathrm{yrs}$ & Married & University & Lansdowne & Volunteer \\
\hline Raymond & $36-45 y r s$ & Single & University & Loan Hills & Employee \\
\hline Winnie & $65+\mathrm{yrs}$ & Married & School & Clarkton & Volunteer \\
\hline Betty & $56-65 y r s$ & Married & School & Bishopton Plots & Volunteer \\
\hline John & $46-55 y r s$ & Single & University & Bishopton Plots & Employee \\
\hline Paul & $46-55 y r s$ & Married & University & Cherish (NGO) & Director \\
\hline Alan & $46-55 y r s$ & Married & University & $\begin{array}{l}\text { Organics (soil } \\
\text { expert) }\end{array}$ & $\begin{array}{l}\text { Self- } \\
\text { employed }\end{array}$ \\
\hline Jillian & $36-45 y r s$ & Married & University & $\begin{array}{l}\text { Wellbeing Centre } \\
\text { (third sector) }\end{array}$ & Manager \\
\hline
\end{tabular}

All interviews were recorded and transcribed, and along with the observations, were opencoded to form initial categories and emergent themes. Feedback was sought from participants on initial results. Coding and interpretation was sensitive to participants' descriptions of 
scale, their interrelations and meanings. Through an iterative process across and within the data initial categories where modified to reveal key relations (Miles and Huberman, 1994). During this process participant observations and interviews were placed in dialogue with each other to facilitate a wide-reaching understanding of the phenomenon under investigation. The analysis process was conducted in parallel by the authors and deliberated until agreement was reached.

\section{Findings and Discussion}

In what follows, we outline and discuss the following: community gardens' broader scalar consciousness in tackling global climate change locally; the blockages and constraints facing community gardens from dominant spatial narratives around neoliberal competitiveness agendas; and the construction of the CFPP as a multi-scalar vehicle for addressing these issues.

\section{Connecting communities to broader sustainability agendas}

Community gardens have been viewed as important in contributing to the creation of more sustainable cities. Comprising a loose heterogeneous network, community gardens represent differing ambitions and are, thus, "places of negotiation" (Massey, 2004) sharing the cityscape but highlighting the simplicity of the term 'community' (Amin, 2002). For some community gardeners they just want "to dig holes in the ground" (Digley Diggers, community garden volunteer), while others wish to reimagine the city through the use of existing derelict sites and peri-urban spaces to promote sustainable food production and consumption, with the attendant environmental benefits. While such differences suggest that a commitment to a broader global responsibility to tackle climate change was the not the only 
imperative behind community gardening, it nevertheless, was invoked frequently by many of those involved. The following quote is typical in this regard:

"If we are serious about climate change we need to talk about food - And all the time! Food is fundamental to human life. It is essential and I don't think we have any choice if [city] is serious about being a sustainable city" (Woodside Community Garden, employee).

The quote also signifies two other important aspects of broader spatial entanglements in developing sustainability agendas. Firstly, the importance of cities to a new sustainable food agenda (Morgan, 2015) but also, secondly, hints at the frustrations community gardens encounter in the city's rhetoric of sustainability versus an existing dominant practice of urban competitiveness. This highlights the need for a broader global consciousness related to climate change that adopts a thorough, systematic and far-reaching local governance commitment to secure more transformative change. This would represent two very different multi-scalar narratives currently in conflict, namely, urban competiveness in a global economy versus a new urban foodscape that addresses global climate change. These narratives are in multi-scalar tension at and across scales; local, national and global, but in the food sector this is also expressed through EU institutions' support for a competitive, mass production agri-food system, and their simultaneous commendable lead role at the global level in setting climate change amelioration targets.

Reconnecting city dwellers with the broader global geographies of food production and consumption and articulating a different more localist ambition is also a critical part of the local-global sustainability imaginary. Morgan, Marsden and Murdoch (2006) talk about the 
necessary shift from a global mass production 'commodity world' of food to a locally integrated, craft-based and knowledgeable 'quality' world. In this regard, community gardens are places where a reconnection is occurring to healthier and more ecologically sustainable forms of food, in ways that are potentially affordable for low-income groups as well as the more affluent 'usual suspect' ethical consumers:

"It's an organic garden so everything is organic. We don't have a lot of money necessarily. They might be buying their seeds from Lidl or whatever but we show them how to collect seeds as well, so they learn the whole process. Everything. We grow wild flowers. A lot of diversity of foods you can eat. And it is good because a lot of people haven't tried a lot of the fruit and veg so that is why we often bring it out at lunchtime and get people to try different things which I think is interesting. But yes it has to be seasonal because they learn all about that. Because of the very nature of the climate. And what we can actually grow here. And we do talk about, a lot of people are on a very low income, so we talk about what you can buy in the shops if you can't grow it yourself." (Secret Garden, employee)

These types of reconnection are critical. As illustrated above, many community gardens are seeking to reconnect urban residents with the source of their food. The dominant agribusiness model distances consumers from production. Such a system has adverse effects on the environment, local economies, social connectedness and personal and community health (Turner, 2011). With urban populations growing, densification will, arguably, further distance individuals from nature. Head and Muir (2006: 522) contend that with a "nature 'out there', the implications for reduced human engagement and empathy with plant and animal others will be considerable". 
DeLind (2006: 143) argues that it is "acts of physical engagement and cultural identification" that will move individuals towards more sustainable lifestyles. The current focus on global commodification processes, enhanced by a broader neoliberal competitiveness agenda overlooks the emotional, expressive, embodied relationships to food and place that results in a deeper connection and experience of sustainability (DeLind, 2006). We witness the experience of body and materiality among individual gardeners, for some with potentially life changing benefits:

"I decided instead of sitting in the house all day, the garden would get me out and about, it gives me something to do... Me being epileptic as well, it [the garden] helps bring down my stress levels with having something on my mind...I was in a bad way, drugs and stuff, working the gardens has saved my life... Sometimes we can come in and do planting, sometimes it is watering, sometimes it is seeding. It just depends" (Gorlands Community Garden, volunteer).

This was by no means an isolated example in our study, or that of others (e.g., Garrett and Leeds, 2015). Local national health services frequently engaged with community gardens, recognising their therapeutic potential for certain patients. Such activities serve to highlight the benefits for individuals in a collective setting. Community gardens can, therefore, help to re-connect people to food in ways that enhance their individual health and well-being and develop a more empowered and outward looking sense of self. In understanding the role of community gardens in contributing to the broader climate change agenda, it is important to recognise that many of the day to day issues around health, wellbeing and increased public engagement through food and growing activities are integral to efforts to create more 
sustainable forms of living. Delivering sustainable transition needs to deal with social injustices created by the failings of the mass industrial food system and broader structural inequalities. These are evident in our case city. In particular, this is evidenced in poor diet and health, lack of knowledge about food and the growing use of food banks. The gardens' ability to re-engage communities, particularly in more deprived areas, around food and growing are important initial steps in creating new behaviours and understandings of the food system. These are critical in creating more sustainable and localised urban food landscapes that challenge the existing and spatially invisible production and consumption relations in the environmentally destructive mass produced global food system (Morgan, 2015).

The role of community gardens in promoting social inclusion and community building has been well documented (e.g., Crossan, et al., 2016). Prugh, Costanza and Daly (2000) argue that community is central to sustainability, providing opportunities for social empowerment at the local scale of everyday life. Our evidence supports the pertinence of a community of scale:

"I have always loved coming to this space. So that is the motivation, give people the chance. It really is that, people who are down on their luck or not well or just want to get involved or do something. Give something back. That whole thing about community. I think because I grew up in a small village as well. Community is really, really important...But some people don't have that. They have moved here and for whatever reason they don't know anyone. So it is a way of starting to make those connections.” (Secret Garden, volunteer) 
Many participants joined community gardens after happening upon one and causally engaging in dialogue with existing gardeners. Such residents see what Boyer (1995) refers to as the "disfigured city", the abandoned sites that surround the contrived "figured city". In doing so they see opportunities to shape new modes of citizenship and democracy through "the power of place" (Hayden, 1995) and in doing so are involved in re-imaging urban life at the broader city scale (MacKinnon, 2011). The very existence of community gardens was motivated by a desire to improve one's neighbourhood:

“The group was set up originally by a group of local residents and people working for local organisations who quite often were residents. And they were sick and tired of the amount of vacant, derelict land there was and the eye sore and the blight on people's lives and the environmental quality aspects that impacts people's lives. People live beside eye sores every day. It is very disheartening. So if that is disheartening on a daily basis what does it do to you overall? So that was why we were set up." (Citizens of Penny Community Garden, volunteer)

Such community places are significant to the memories, connections, experiences and relationships that hold people together (Lockwood, 1999; Delind, 2006). Here, they also play a more fundamental role as emergent and open spaces (Massey, 2005) that project outwards a very different and more progressive narrative of the city.

\section{Multi-scalar blockages and contestations}

It is important to acknowledge, however, the precarious existence of community gardens operating in a broader neoliberal urban environment where a competitive discourse and, in our case a dominant property-led regeneration agenda, dominates and is a barrier to more 
sustainable practices. Since 2010, the city council's promotion of sustainable food and community gardening, as part of its mission to make the city one of the most sustainable in Europe, conflicts with the outsourcing of all its land and properties to an arms length company, tasked with realising full commercial value and enacting by charging all community groups and activities market rate rents (Nolan, 2015). As illustrated in quote below, this has led to community gardens in the city being bulldozed and destroyed by developers without notice, although this seems to have subsided recently, partly because of the greater acceptance at city and national governance levels of the beneficial social and ecological role that community gardens can play. Critics of community gardens also highlight the potential for them to be co-opted into broader gentrification efforts with volunteer unpaid labour helping to renovate disused city spaces for new rounds of property led development (McClintock 2014), although this is not something that has been particularly evident, to-date, in our case study.

While the broader literature advocates large-scale policy initiatives (e.g., Pothukuchi and Kaufman, 1999; Holland, 2004; Drescher, Homer and Iaquinta, 2006), particularly in relation to urban planning, in providing adequate spaces and secure land tenure critical to sustainable development (Turner, 2011), we find that a top-down urban commodification agenda helps to sustain a general lack of security of tenure for community garden groups:

"He will be able to tell you better but they basically have a site similar to us where developers work. It was on Avenue Lane so they had a community garden there and they had tried to get in contact with the landowner but had failed. They hadn't heard anything back so they went ahead and effectively worked on it as if it was a stalled space. So it might be a year before it is built on or it might be 50 years. But what 
actually happened was that a developer decided on a moment's notice that he wanted to develop on it. He didn't want loads of raised beds on it so he sent in the bulldozers and effectively bulldozed the whole site. So that is obviously an issue because if you are working on a site where you don't know what is happening in the near future or in the distant future. And you don't have any say because you are not the owner, then obviously it is precarious situation to be in. You have to pack up, find yourself a new site. It is pretty difficult. So in terms of long term development of a project or growing an orchard or something that takes a few years to establish then you need to know that that land is still going to be available to cultivate five ten years down the line or it is just a waste of time.” (Greenlands Community Garden, volunteer)

Lease ambiguities result in temporal uncertainties. This creates anxieties in community garden groups in terms of how much money and time is worth investing in the space and a range of practical challenges concerning the longer term planning of the gardens. Community gardens that occupied sites without any lease agreement were vulnerable to eviction and in some cases, as highlighted above, destruction of their efforts. One such site was used and maintained by the community during an eight year campaign to protect it from a planned housing development. In a decision that saw the campaign reach national government, through the utilisation of media outlets and local community social capital, the common result in favour of property development over green community space was reversed in a decision that rejected the developers planning application. Three of the community gardens in our study had no lease agreement with the landowners, and another three had an informal operating agreement with the landowner. More still had free or concessionary rents based on a rolling contract. Rolling contracts make it more difficult for garden groups to access funding, as some funders require that the group have a more stable lease arrangement in 
place. Only two of the gardens we visited had a fixed term contract for their lease; most struggled to engage landowners, including the city council:

"On that point, I think one of the problems is that a lot of these ones from the councils, that are hearing about it, they are reading about it, they are not actually getting to see it because they are not actually coming down themselves and having a look and talking to people. All they are thinking about is getting a piece of paper, reading it, thinking we don't need to think about that, just get rid of that or keep it, whatever...Come down and try it themselves and actually see what actually comes out of it and maybe pay more attention to it. And with that they'll see a different side to it." (Gordonstone Community Garden, volunteer)

What such remarks clearly signify is something of a scalar chasm between community groups working to transform urban practice for social and environmental purposes at the neighbourhood level, yet largely invisible to urban planning and governance professionals and property developers producing top-down strategies for urban renewal around maximising the exchange value of land. In moving beyond what Morgan Marsden and Murdoch (2006) refer to as "placeless foodscapes", the community gardens face the imperative to make their actions and practices visible to critical higher level political actors, particularly at the scale of the city council and national government.

Only through producing higher scale visibility of the potential benefits of community gardens can their potential in helping to address climate change and sustainable food agendas be realised. Community gardens are active sites of environmental education, nurturing, incidental, self-directed and non-formal learning practices. We also found examples where 
community garden staff were playing a much wider role across the city in training and educating diverse groups in relation to food production and gardening. One group was particularly active in assisting in the establishment of new gardens, offering opportunities for dispersion at scale horizontally of food growing practices. To varying degrees, each learning practice requires trained educators. Third sector organisations and the city council provided many of the city's community gardens with the staff required to fulfil these roles, however, a concern was expressed over a 'green skills gap' in the city. For example, at the time of writing the city council employed only one green space officer for the whole city. To take environmental sustainability and climate change seriously would require a commitment by stakeholders to begin training future educators in horticulture and other land-based subjects.

While community gardens are negatively affected by broader agendas operating at the scale of the city as a whole, they do have their own existing multi-scalar networks, including at the level of the city council itself. A variety of organisations, from government bodies to charities, offer competitive funding, support and expertise for communities. However, such streams have been impacted by broader urban austerity policies (Featherstone et al., 2012; Peck, 2017). A number of funding related challenges faced by community garden groups were identified, including, increased competition for funding between groups, thus, negatively impacting the potential for groups to form strategic alliances that would facilitate the pooling of resources among groups. Those groups that operate in relative proximity to one another were more likely to raise this concern. Additionally, the funding environment can and does remove agency from community garden organisations as they become constrained by the broader structural conditions of particular national funding agreements rather than setting their own agendas and strategies. Many participants complained about what they perceive to be "a lack of joined up thinking" and "fragmentation" in the current funding 
landscape. Navigating this landscape involves multiple applications for different aspects of the gardens.

Faced with these dilemmas, the CFPP can be seen as a multi-scalar strategy (MacKinnon, 2011) to develop a broader city level agenda for community gardening that enrols key actors at city and national scales of governance, alongside key NGOs and third sector groups. We turn our attention this below.

\section{An exercise in scalar politics: the construction and operation of the CFPP}

A series of sustainable food events were held in the case city during 2014. At the close of one event a multi-stakeholder group of actors, from the city council, community gardeners, academics, government and non-government organisations and health services, voluntarily gathered to discuss the outcomes of the event. Upon the suggestion of one of the gathered party, the CFPP was spontaneously born to unanimous agreement, as a means to progress sustainable food issues in the city of which supporting community gardens is one element. Others are tackling food waste, food poverty and encouraging short food supply chains. With fifteen members at the time of writing, the CFPP describes itself as:

\footnotetext{
"A strategic grouping bringing together key public, private and voluntary sector organisations with the objective of achieving a fairer, healthier, more sustainable and resilient food system in [city]" (CFPP, minute).
}

From the outset, its multi-scalar construction was a critical element of the CFPP in progressing a sustainable food agenda. For community growers, the formation of the partnership was welcomed as an opportunity to provide access to, for example, city council 
representatives, a scale at which community gardens experienced tensions and ongoing negotiation in terms of land access, tenure and rent. Community gardeners felt that the city council could and should play an important role in enabling community gardens. The CFPP, therefore, provided an opportunity to confront and, potentially, resolve multi-scalar tensions.

Having partners in the CFPP who represent national government, national health service and food sector NGOs also created a space for creating a broader discourse around sustainable food that could link up local action to broader governance initiatives and structures. This can be evidenced by the following two examples. First, CFPP members from the local university, city council, grassroots NGOs, together with officers from a government funded community hub in a deprived area of the city were successful in attaining EU/Government social innovation funding. This funding will seek to engage community residents in the creation of a food hub that can showcase local, healthy and more sustainable food practices, including community growing, in an area that has become a 'food desert' due to the decline and closure of local shops. Loss of local shops has been, in part, the result of 'regeneration' of the area and the subsequent destruction of existing premises to make way for a high profile event hosted by the city.

Second, CFPP members have been working with city council officers since November 2016 to facilitate the city's local food growing strategy, required as part of recent government legislation. One outcome of this has been the development of a digital map of potential food growing spaces across the city, with the aim of expanding community gardening into nearby and new neighbourhoods. The city council now has a stated objective of creating more "short food supply chains" in pursuit of its sustainability agenda (CFPP, minute). Multi-scalar action 
by the CFPP is, thus, beginning to challenge the dominant property based urban regeneration narrative on behalf of community gardens within the city council.

The CFFP has also become a vehicle for integrating food production and community gardening activity within much broader health and well-being initiatives. As part of a broader remit around sustainable food, including, food poverty, waste and health, community growing was deemed an important focus for the CFPP, as one member illustrates:

"I think that in terms of contribution to meeting people's nutritional needs urban agriculture could probably contribute about $10 \%$ of [country] fruit and veg quite easily from the amount of ground space we have got. If you look at [neighbouring city] you have 600 acres of space, you can do 10 tonnes an acre, 6,000 tonnes. $£ 600$ of combination, that's $10 \mathrm{~kg}$ per person per year of veg from derelict land, so there is potential there...there are a few reasons you would do that. One thing is nutritional value, particularly of fresh greens is much higher if you can get them pretty close to...straight out of the ground. You just retain more of the nutrients and the general goodness of having these things. Spinach doesn't travel very well, but also quite an amount of effort in the food chain, trying to keep it cold, moving long distances, storing it for 2, 3, 4 days, putting it on the shelf and wrapping in plastic it is just an enormous waste of time and energy for folks if you can do that locally." (CFPP member)

Within the CFPP community gardening was deemed critical as part of a strategy for envisaging a very different kind of food city, built around principles of sustainability. This was not to view community gardens as a mechanism to feed the city's population as a whole 
but rather to support neighbourhood access and connection to affordable, healthy food. The majority of the community gardeners in our research identified the need for some form of citywide support and strategy. Such an approach would be sensitive to the varying ambitions among the city's growers from those that wish to feed themselves at the scale of the individual to those seeking a more technically advanced form of urban agriculture:

...the transformation of agribusiness where the movement is being made away from large monoculture industrial farming to smaller scale intensified farming, utilising at the moment grossly underutilised smallholdings around the cities, so I foresee...that the interaction between urban agricultural and peripheral urban smallholdings with intensified farming, where this intensified farming is coupled with food processing and then distribution of high quality food stuffs from the same set ups which greater urban peripheral smallholdings lend themselves to ideally. So this is then for the future, creating opportunity, creating business, creating skill sets for business training, or agriculture based with urban and greater urban which is semi-rural agriculture interlinked where we can find the skills sets in these communities...We don't have the structure in place. There's a lot of pioneering thinking on the ground at the moment already which I am very proudly associated with... (Cowhill Community Garden, employee)

Securing greater access to derelict sites for community food growing is critical to a city-wide vision but requires greater city and even national scale action and influence. The mechanisms to achieve this at community level are limited. Thus, those local groups seeking to reimagine the city around urban agriculture were aware that access to 'higher' scales, was necessary to realise their vision. In securing its position as representing community interests, the CFPP has 
secured national government funding on two occasions: first, to explore, through consultation and a feasibility study, the potential for a community food network in the city, and, second, following a positive response, to realise this vision. Here there is an attempt to re-empower communities locally with the CFPP as a vehicle for articulating and lobbying for community food spaces at higher scales (Massey, 2005). While there was a genuine desire within the CFPP to ensure that communities have an influencing voice in the group, at the time of writing, there is one community grower representative on the CFPP ${ }^{1}$. Community representation is challenging, given the absence of a formal network of city growers through which information can flow. Indeed, the tensions that this can create were illustrated as the CFPP community grower representative sought to take forward outcomes from the government funded consultation exercise. Following a consultation event and feasibility study, it was revealed that community growers were broadly supportive of the creation of an umbrella organisation for community food groups and the potential opportunities afforded from working together, sharing resources, building capacity and having a collective voice at the scale of the city. The CFPP community member, however, faced significant concerns that questioned how a single voice could represent a fluid sector and how this could be genuinely representative and accountable, both in terms of their ability individually to represent the sector and how a community food network could achieve such an ambition. Throughout community exchanges, however, there was an overriding desire to work together through constructive engagement to achieve an effective voice at the level of the city and nationally. As the CFPP positions itself as a group that seeks to influence rather than enact change, the need for communities to take ownership of their interests in this space was an important aim. The CFPP is seeking to scale up and empower community gardens and discourses around

\footnotetext{
${ }^{1}$ There had been more community growers involved during formation of the CFPP and initial meetings. However, as part of a move to reduce multiple representation from a given group or organisation a decision was taken that one person could seek to feedback between the CFPP and community growers in the city.
} 
sustainability at the city and national level, while at the same time having a narrative about empowering communities at the local scale. We observe a tension between dominant scalar management practices embedded in city and national institutions and more radical grassroots autonomy. Community gardeners desired a re-imagining of the city to support growing and sustainability. Such a vision, however, would demand a radical re-thinking of current policies around planning, access to land and resources and skills development and the required allocation of resources to support community, feeding into, city-wide initiatives. Legislation passed in 2015 has the potential to facilitate community growing, however, the challenges of scale jumping at both the community and urban level present challenges in the realisation of these opportunities. For such opportunities to be effective national and city institutions must engage with and create mechanisms that genuinely empower community groups. While the current government funding awarded to the CFPP takes steps in this direction, tensions across and within scale present challenges to the realisation of this vision.

Representative membership more generally has been an on-going and unresolved tension since the formation of the CFPP. This is critical as it determines whose knowledge is drawn upon and, thus, who shapes the process. Often boundaries between the partnership, its members and the organisations of which they are a part are blurred. It can be unclear when a member is espousing their individual view or acting as a representative of their organisation. Further, within a single institution multiple narratives can co-exist. For example, the CFPP seeks to support access to community gardening and has signed up to the sustainable food city network. Partnership members from the city council have endorsed this position, while at the same time the city council has a branch that seeks commercial rents for vacant city sites, a constructive barrier to community growing initiatives. Here we witness tensions between an 
underlying neoliberal agenda and attempts to re-envision sustainability in the city and the genuine challenges in negotiating competing agendas across scale.

\section{Conclusion}

Developing effective forms of organisation and strategy to tackle climate change is one of the biggest management issues facing humankind in the next twenty years. In this paper, we have contributed to this agenda through exploring the multi-scalar dilemmas facing community groups in promoting sustainability initiatives at the local neighbourhood level. Our case study of community gardening in a large UK city reveals three key findings for broader management thinking.

First, at a conceptual level, to be effective, a scalar approach to sustainability transitions should not take scale as fixed or pre-given but should adopt the more fluid relational approach of scalar politics (MacKinnon 2011). As we have shown here, such an approach allows us to identify both how broader spatial visions are articulated locally (Massey 2004), as well as the changing multi-scalar landscape of governance facing local groups with the tensions, constraints and different agendas at different scales that community food growing groups have to engage. Such an approach also highlights the potential for community gardeners to 'jump scale' in drawing upon their own wider spatial networks, as well as enlisting support at higher scales to help empower a more bottom-up community agenda. Movement across scale is vital, at the local level while community gardens differed in geography, neighbourhood, size and ambition, they did experience a set of shared struggles in gaining access to debates around broader urban governance. Enlisting city and national government actors was viewed as a means to address these challenges. 
Second, we document the construction of a particular multi-scalar grouping, namely, the CFPP. While grappling with the challenges of representative and conflicting scalar narratives, the CFPP does offer a forum supportive of community growing initiatives that did not previously exist in the city. This affords community growers the opportunity to jump scale in pursuit of their interests and the CFPP to jump scale in their desire to represent community interests. The CFPP views its role as supportive and advisory, thus, highlighting the importance of connections to wider scales for fostering sustainability. The CFPP already connects with key experts at city and national scales through invited talks to the group. Recent legislation has resulted in consultations with the group by city government officials over the development of a city food growing strategy. Indeed, since the formation of the CFPP there have been no reported community garden evictions and a marked increase in the number of community garden projects.

Finally, food is an important vehicle by which to consider the multiple and differing scales that integrate the economic, social and environmental dimensions of sustainability and, as such, represents an important means by which to understand and tackle the interrelated socioeconomic, cultural, political and ecological processes at play (Lang et al, 2009). Delind (2006) argues against a sustainable food system built around "economic assessment and arguments", claiming that such a narrative will "carry with it the seeds of its own destruction", embedded as it is within dominant development perspectives. Alternative multiscalar narratives and strategies around food, such as those evident in this research, reveal the tensions that exist at all scales - from the local neighbourhood, to the city, to the national and even beyond to EU initiatives - in the battle between a continuing economic agenda around growth and marketisation versus social and environmental sustainability. 


\section{References}

Amin, A. (2002). 'Ethnicity and the multicultural city: living with diversity', Environment and Planning A, 34, pp. 959-980.

Black, I. R., Shaw, D., and Trebeck, K. (2017). 'A Policy Agenda for Changing our Relationship with Consumption', Journal of Cleaner Production, 154, pp. 12-15.

Boyer, M. C. (1995). The Great Frame-Up: Fantastic Appearances in Contemporary Spatial Politics. In H. Liggett and D. C. Perry, (eds.) Spatial Practices: Critical Explorations in Social/Spatial Theory. London: Sage, pp. 81-109.

Carrington, M. J., D. Zwick and B. Neville, B. (2016). 'The ideology of the ethical consumption gap', Marketing Theory, 16, pp. 21-38.

Crossan, J., Cumbers, A., McMaster, R., and Shaw, D. (2016). 'Contesting Neoliberal Urbanism in Glasgow's Community Gardens: The Practice of DIY Citizenship', Antipode, 48, pp. 937-955.

Cox, K. (1998). Spaces of Globalization: Reasserting the Power of the Local. New York, Guilford.

Cumbers, A. (2015). Constructing a global commons: in, against and beyond the state. Space and Polity, 19, pp. 62-75,

Delind, L. B. (2006). 'Of bodies, place, and culture: Re-situating local food', Journal of Agricultural and Environmental Ethics, 19, pp. 121-146.

Devine-Wright, P. (2013). 'Think global, act local? The relevance of place attachments and place identities in a climate changed world', Global Environmental Change, 23, pp. 61-69. Drescher, A.W., Holmer, R.J., and Iaquinta, D.L. (2006). 'Urban home gardens and allotment gardens for sustainable livelihoods: management strategies and institutional environments'. In: B. M. Kumar and P. K. R. Nair, eds. Tropical home gardens: a time-tested example of sustainable agroforestry. The Netherlands: Springer, pp. 317-338. 
Featherstone, D. (2008). Resistance, Space and Political Identities: the Making of CounterGlobal Networks. Oxford, Blackwell.

Featherstone, D. Ince, A. MacKinnon, D. Strauss, K. Cumbers, A. (2012) Progressive localism and the construction of political alternatives. Transactions of the Institute of British Geographers, 73, pp. 177-82.

Ferris, J., Norman, C., and Sempik, J. (2001). 'People, land and sustainability: community gardens and the social dimension of sustainable development', Social Policy and Administration, 35, pp. 559-568.

Garrett, A. and Leeds, M. A. (2015). 'The economics of community gardening', Eastern Economic Journal, 41, pp. 200-213.

Geels, F.W. (2010). 'Ontologies, socio-technical transitions (to sustainability), and the multilevel perspective', Research Policy, 39, pp. 495-510.

Geels, F. (2014). 'Regime Resistance against Low-Carbon Transitions: Introducing Politics and Power into the Multi-Level Perspective', Theory, Culture, Society, 31, pp. 21-40.

Glover, T. D. (2003). 'The story of Queen Anne Memorial Garden: resisting a dominant cultural narrative', Journal of Leisure Research, 35, pp. 190-212.

Harvey, D. (1989). 'From managerialism to entrepreneurialism: the transformation in urban governance in late capitalism', Geografiska Annaler B, 71, pp. 3-17.

Hayden, D. (1995). The Power of Place. Cambridge, MA: MIT Press.

Head, L. and Muir, P. (2006). 'Suburban life and the boundaries of nature: resilience and rupture in Australian backyard gardens', Transactions of the Institute of British Geographers, 31, pp. 505-524.

Hoenkamp, R. Huitema, G.B. de Moor-van Vugt, A. (2011). 'The neglected consumer: the case of smart meter roll-out in the Netherlands', Renewable Energy, Law and Policy Review 4, pp. 269-282. 
Holland, L. (2004). 'Diversity and connections in community gardens: a contribution to local sustainability', Local Environment, 9, pp. 285-305.

Jones, C. A. (2010). 'The subject supposed to recycle', Philosophy Today, 54, pp. 30-39. Kingsley, J. and Townsend, M. (2006). 'Dig in' to social capital: Community gardens as mechanisms for growing urban social connectedness', Urban Policy and Research, 24, pp. $525-537$.

Kozinets, R. V. (2002). 'Can consumers escape the market? Emancipatory illuminations from Burning Man', Journal of Consumer Research, 29, pp. 20-39.

Lang, T., Barling, D. and Caraher, M. (2009). Food Policy: Integrating Health, Environment and Society. Oxford: Oxford University Press.

Lawson, T. (1997). Economics and Reality. London: Routledge.

Kingsley, J. and Townsend, M. (2006). 'Dig in” to social capital: community gardens as mechanisms for growing urban social connectedness', Urban Policy and Research, 24, pp. $525-537$.

Lockwood, J. A. (1999). Agriculture and biodiversity: finding our place in this world, Agriculture and Human Values, 16, pp. 365-379.

MacKinnon, D. (2011). 'Reconstructing scale: Towards a new scalar politics', Progress in human geography, 35, pp. 21-36.

MacKinnon, D. and Derrickson, K. (2013). 'From resilience to resourcefulness: a critique of resilience policy and activism', Progress in Human Geography, 37, pp. 253-70.

MacLeod, G. (2001). 'From urban entrepreneurialism to a 'Revanchist City'? On the spatial injustices of Glasgow's Renaissance', Antipode, 34, pp. 602-624.

McClintock, N. (2014). 'Radical, reformist, and garden-variety neoliberal: coming to terms with urban agriculture's contradictions', Local Environment 19, pp. 147-71

Massey, D. (2005). For Space. London: Sage. 
Massey, D. (2004). 'Geographies of responsibility', Geografiska Annaler: Series B, Human Geography, 86, pp. 5-18.

Miles M. B. and Huberman A. M. (1994). Qualitative Data Analysis: An Expanded Sourcebook. Thousand Oaks, CA: Sage Publications.

Morgan, K. J. (2015). Nourishing the city: the rise of the urban food question in the global north. Urban Studies 52(8), pp. 1379-1394

Morgan K Marsden T and Murdoch (2006). Worlds of Food: Place, Power and Provenance in the Food Chain. Oxford University Press

Moragues-Faus, A. and Morgan, K. (2015). 'Reframing the foodscape: the emergent world of urban food policy', Environment and Planning A, 47, pp. 1558-1573.

Moskow, A. (1999). 'Havana's self-provision gardens', Environment and Urbanization, 11 , pp. $127-134$.

Nolan, L.J. (2015) Space, Politics and Community: the Case of Kinning Park Complex. PhD thesis, Glasgow, University of Glasgow.

Peck, J. (2017 in press) .Transatlantic City, Part 1: Conjunctural Urbanism. Urban Studies Transatlantic city, part 1: conjunctural urbanism. 54.

Porter, M. (1990). The Competitive Advantage of Nations. New York, Free Press.

Pothukuchi, K. and Kaufman, J. L. (1999). 'Placing the food system on the urban agenda: the role of municipal institutions in food systems planning', Agriculture and Human Values, 16, pp. 213-224.

Prugh, T., Costanza, R. and Daly, H. (2000). The local politics of global sustainability. Washington: Island Press.

Saldivar-Tanaka, L. and Krasny, M. E. (2004). 'Culturing community development, neighbourhood open space, and civic agriculture: the case of Latino community gardens in New York City',Agriculture and Human Values, 21, pp. 399-412. 
Sassatelli R (2015) Consumer Culture, Sustainability and a New Vision of Consumer Sovereignty. Sociologia Ruralis. Published Online.

Smith N (1993) Homeless/global: scaling places. In: Bird J, Curtis B, Putnam T, et al. (eds) Mapping the Future: Local Cultures, Global Change. London: Routledge, pp.87-119. Smith, N. (1996). The New Urban Frontier: Gentrification and the Revanchist City. London, Routledge.

Stocker, L. and Barnett, K. (1998). 'The significance and praxis of community-based sustainability projects: community gardens in Western Australia', Local Environment, 3, pp. $179-189$.

Strang, V., 2004. The meaning of water. Oxford: Berg.

Swyngedouw, E. (1997). 'Neither Global nor Local: 'Glocalization' and the Politics of Scale'. In, Keith Cox (ed.), Spaces of Globalization. New York: Guildford, pp. 137-166. Tan, L. H. H. and Neo, H. (2009). ““Community in bloom”: local participation of community gardens in urban Singapore', Local Environment, 14, pp. 529-539.

Turner, B. (2011). 'Embodied connections: sustainability, food systems and community gardens', Local Environment, 16, pp. 509-522.

Wolfe, D. A. (2010). 'The strategic management of core cities: Path dependence and economic adjustment in resilient regions', Cambridge Journal of Regions, Economy and Society, 3, pp. 139-152. 